\title{
Evidence for In Vivo Uprëgulation of the Intestinal Vitamin D Receptor during Dietary Calcium Restriction in the Rat
}

\author{
Murray J. Favus, David J. Mangelsdorf, ${ }^{\ddagger}$ Vrishali Tembe, Brian J. Coe, and Mark R. Haussler \\ Department of Medicine, The University of Chicago Pritzker School of Medicine, Chicago, Illinois 60637; and \\ ${ }^{\ddagger}$ Department of Biochemistry, University of Arizona Health Sciences Center, Tucson, Arizona 85724
}

\begin{abstract}
1,25-Dihydroxyvitamin $\mathrm{D}_{3}\left[1,25(\mathrm{OH})_{2} \mathrm{D}_{3}\right]$ increases intestinal calcium absorption through events that include binding of $1,25(\mathrm{OH})_{2} \mathrm{D}_{3}$ to the intracellular vitamin $\mathrm{D}$ receptor. In vitro studies using mammalian cell cultures reveal an increase in vitamin $D$ receptor content after exposure to $1,25(\mathrm{OH})_{2} \mathrm{D}_{3}$. To test the hypothesis that $1,25(\mathrm{OH})_{2} \mathrm{D}_{3}$ increases enterocyte vitamin $D$ receptor content in vivo, male rats were fed either a normal calcium diet (NCD, 1.2\% Ca) or low calcium diet (LCD, $0.002 \% \mathrm{Ca})$. After $21 \mathrm{~d}$ LCD increased serum $1,25(\mathrm{OH})_{2} \mathrm{D}_{3}$ levels $(27 \pm 3$ vs. $181 \pm 17 \mathrm{pg} / \mathrm{ml}, P<0.001)$ and increased transepithelial mucosal to serosal calcium fluxes $\left(J_{\mathrm{ms}}\right)$ across duodenum $\left(65 \pm 21\right.$ vs. $204 \pm 47 \mathrm{nmol} / \mathrm{cm}^{2} \cdot h, N C D$ vs. LCD, $P$ $<0.01)$ and jejunum $(23 \pm 3$ vs. $46 \pm 4, P<0.007)$. No change in serosal to mucosal calcium fluxes $\left(J_{\mathrm{sm}}\right)$ were observed. LCD increased $1,25(\mathrm{OH})_{2} \mathrm{D}_{3}$ receptor number threefold in duodenum (32.9 \pm 6.7 vs. $98.7 \pm 13.7 \mathrm{fmol} 1,25(\mathrm{OH})_{2} \mathrm{D}_{3} / \mathrm{mg}$ protein) and jejunum (34.1 \pm 9.5 vs. 84.9 \pm 7.7$)$ without a change in the receptor affinity for $1,25(\mathrm{OH})_{2} \mathrm{D}_{3}\left(K_{d}\right.$ is $0.17 \pm 0.06$ vs. $0.21 \pm 0.02 \mathrm{nM}$ for NCD and LCD duodenum, respectively). Duodenal polyadenylated vitamin D receptor mRNA determined by Northern blot analysis did not increase appreciably during LCD, suggesting that upregulation in vivo may not be due primarily to increased receptor synthesis.

The results of this study indicate that under physiologic conditions as during chronic dietary calcium restriction, increased intestinal vitamin D receptor content accompanies increased calcium active transport. Upregulation of the vitamin $D$ receptor by $1,25(\mathrm{OH})_{2} \mathrm{D}_{3}$ may result primarily from posttranslational processes that decrease degradation of the receptor with increased receptor synthesis responsible for a negligible portion of the accumulation.
\end{abstract}

\section{Introduction}

Small intestinal absorption of dietary calcium occurs by a paracellular pathway driven by osmotic and concentration gradients and a cellular active transport process that is regu-

This work was presented in part at the annual meeting of the American Society for Bone and Mineral Research, 9 June 1987, Indianapolis, IN and has appeared in abstract form (1987. J. Bone Mineral Res. 2[Suppl. 1]:Abstr. 507).

Address reprint requests to Dr. Favus, Box 28, The University of Chicago, 5841 South Maryland Avenue, Chicago, IL 60637.

Received for publication 19 August 1987 and in revised form 28 December 1987.

J. Clin. Invest.

(C) The American Society for Clinical Investigation, Inc. $0021-9738 / 88 / 07 / 0218 / 07 \$ 2.00$

Volume 82, July 1988, 218-224 lated by 1,25 -dihydroxyvitamin $\mathrm{D}_{3}\left[1,25(\mathrm{OH})_{2} \mathrm{D}_{3}\right](1-3)$. The intestinal actions of $1,25(\mathrm{OH})_{2} \mathrm{D}_{3}$ occur through a complex series of events that are initiated by binding of the steroid hormone to a specific intracellular protein, the vitamin $D$ receptor (4-7). Events that follow include nuclear localization of the $1,25(\mathrm{OH})_{2} \mathrm{D}_{3}$ receptor complex and regulation of hormone-sensitive genes, most likely through binding to DNA (8-10).

Whereas the cellular binding of $1,25(\mathrm{OH})_{2} \mathrm{D}_{3}$ to its receptor and subsequent genomic events are similar to those described for other steroid hormones, including estrogens, progesterone, glucocorticoids, and androgens (10), unlike most other hormones, $1,25(\mathrm{OH})_{2} \mathrm{D}_{3}$ increases rather than decreases the content of its receptor in target cells. The addition of $1,25(\mathrm{OH})_{2} \mathrm{D}_{3}$ to mammalian cultured cells increases the intracellular content of the vitamin D receptor protein (11-13) and its mRNA $(13,14)$. Because the accumulation of the vitamin $D$ receptor is temporally related to the known actions of $1,25(\mathrm{OH})_{2} \mathrm{D}_{3}$ to decrease collagen and osteocalcin synthesis in rat osteoblastlike cell primary cultures (12) and induce 25-hydroxyvitamin $D_{3}$-24-hydroxylase activity in human skin fibroblasts (15), upregulation of the vitamin $\mathrm{D}$ receptor is thought to be involved in amplifying the biologic actions of $1,25(\mathrm{OH})_{2} \mathrm{D}_{3}$.

Little information is available to determine whether the in vitro phenomenon of homologous upregulation of the vitamin $D$ receptor plays a role in vivo in the physiologic regulation of intestinal calcium transport. The vitamin $D$ receptor is present in the intestine of vitamin D-deficient chicks $(13,16)$ and rats (17-19), and Costa and Feldman (19) reported a 30\% increase in intestinal vitamin $\mathrm{D}$ receptor content upon acute repletion of $1,25(\mathrm{OH})_{2} \mathrm{D}_{3}$ in vitamin $\mathrm{D}$-deficient rats (19). Because the increase in receptor content in vivo is modest compared with the two- to fourfold increase observed in vitro $(11,20)$, studies were performed to determine whether upregulation of the vitamin D receptor may also occur in vivo in vitamin D-replete animals. Rats were fed a low calcium diet (LCD) ${ }^{1}$ for 3 wk because chronic dietary calcium restriction is known to increase renal $1,25(\mathrm{OH})_{2} \mathrm{D}_{3}$ synthesis (21), circulating $1,25(\mathrm{OH})_{2} \mathrm{D}_{3}$ levels $(21,22)$, and calcium active transport across small intestine $(3,23)$. In the present study dietary calcium restriction increased intestinal vitamin $\mathrm{D}$ receptor content threefold, suggesting that under physiologic conditions upregulation of the vitamin $\mathrm{D}$ receptor may be one way in which $1,25(\mathrm{OH})_{2} \mathrm{D}_{3}$ stimulates intestinal calcium absorption.

\section{Methods}

Animals and diets. Male Sherman rats (Camm Research Institute, Wayne, $\mathrm{NJ}$ ) weighing $150-170 \mathrm{~g}$ were randomized into two groups, fed

1. Abbreviations used in this paper: $G_{\mathrm{t}}$, tissue conductance; $I_{\mathrm{sc}}$, short circuit current; $J_{\mathrm{ms}}$, flux from mucosa to serosa; $J_{\mathrm{sm}}$, flux from serosa to mucosa; LCD, low calcium diet; NCD, normal calcium diet. 
either a normal calcium diet (NCD: $1.2 \% \mathrm{Ca}, 0.9 \% \mathrm{P}, 0.24 \% \mathrm{Mg}$, and $2.2 \mathrm{IU}$ vitamin $\mathrm{D} / \mathrm{g}$ ) or a low calcium diet (LCD: $0.002 \% \mathrm{Ca}, 0.34 \% \mathrm{P}$, $0.24 \% \mathrm{Mg}$, and $2.2 \mathrm{IU}$ vitamin $\mathrm{D} / \mathrm{g}$ ), and provided deionized distilled water ad libitum for 3 wk. Animals were killed by exsanguination through the abdominal aorta, and segments of duodenum $(3 \mathrm{~cm}$ distal to the pylorus) and jejunum (middle $30 \mathrm{~cm}$ of small intestine) were removed for measurements of bidirectional calcium fluxes. Intestinal $1,25(\mathrm{OH})_{2} \mathrm{D}_{3}$ receptor content was determined using $10-\mathrm{cm}$ duodenal and 10-cm jejunal segments obtained from a separate group of animals raised in an identical manner. Duodenum was chosen for study because of the well known effect of LCD to increase $1,25(\mathrm{OH})_{2} \mathrm{D}_{3}$-mediated duodenal net calcium absorption (3). Jejunum was used because, in contrast to duodenum, net calcium transport increases only modestly in response to $1,25(\mathrm{OH})_{2} \mathrm{D}_{3}(3)$.

In vitro calcium transport. Adjacent segments of duodenum or jejunum were rinsed in ice-cold saline and mounted as the partition between two Lucite hemichambers with an exposed tissue area of 0.49 $\mathrm{cm}^{2}$. Mucosal and serosal surfaces were bathed in $10 \mathrm{ml}$ of bicarbonate buffered Krebs-Ringer solution ( $\mathrm{pH}$ 7.4) containing (in millimolar): $\mathrm{NaCl}, 120 ; \mathrm{NaHCO}_{3}, 25 ; \mathrm{KCl}, 5 ; \mathrm{CaCl}_{2}, 1.25 ; \mathrm{MgSO}_{4}, 1.2$; and D-glucose, 11. Reservoirs were gassed continuously with $95 \%$ oxygen-5\% carbon dioxide to maintain $\mathrm{pH}$ at 7.4 and ensure adequate mixing. Unidirectional transepithelial fluxes of calcium were measured as previously described (24). ${ }^{45} \mathrm{Ca}$ as $\mathrm{CaCl}_{2}$ was added to either the mucosal or serosal reservoirs. Aliquots from the initially unlabeled reservoirs were removed at 20 -min intervals and counted for ${ }^{45} \mathrm{Ca}$ content in a liquid scintillation spectrometer (model 4530, Packard Instrument Co., Inc., Downers Grove, IL). Steady-state fluxes from mucosa to serosa $\left(J_{\mathrm{ms}}\right)$ and from serosa to mucosa $\left(J_{\mathrm{sm}}\right)$ were calculated by the method of Schultz and Zalusky (25). Net flux $\left(J_{\text {net }}\right)$ is the difference between the two unidirectional fluxes where positive values indicate net absorption.

Spontaneous electrical gradients across the epithelium were neutralized by a continuous short-circuit current according to the method of Field et al. (26), except for brief periods of interruption to measure tissue potential difference. Steady-state fluxes from each rat were used in the data analysis only if the tissue conductance $\left(G_{t}\right)$ of the paired tissues agreed within $30 \%$.

$1,25(\mathrm{OH})_{2} D_{3}$ receptor. Intestinal receptor-rich cytosol fraction was prepared according to the method of Feldman et al. (18). Rats were killed and intestinal segments removed and flushed immediately with ice-cold saline. All subsequent steps were performed at 0 to $4^{\circ} \mathrm{C}$. Segments were slit open along the mesenteric attachment, and the mucosa was scraped from the underlying muscle layers with a chilled glass slide. The mucosa was suspended in 10 vol of calcium- and magnesium-free phosphate-buffered saline containing $5 \mathrm{mM}$ dithiothreitol (DTT) and centrifuged at $200 \mathrm{~g}$ for $5 \mathrm{~min}$ in a refrigerated centrifuge (Sorvall RC-5C with SS 34 rotor, DuPont-Sorvall, Newtown, CT). The wash was repeated three times. The washed mucosa was sonicated on ice in hypertonic buffer composed of (in millimolar): $\mathrm{KCl}, 300$; Tris$\mathrm{HCl}$ (pH 7.4), 10; EDTA, 1; Na molybdate 10; and DTT, 5. The homogenate was centrifuged at $115,000 \mathrm{~g}$ for $60 \mathrm{~min}$ in an ultracentrifuge (model L2-65B with Ti 60 rotor, Beckman Instruments, Inc., Fullerton, CA). The supernate cytosol fraction containing the vitamin $D$ receptor was collected for assay of $1,25(\mathrm{OH})_{2} \mathrm{D}_{3}$ binding.

$1,25(\mathrm{OH})_{2} \mathrm{D}_{3}$ receptor saturation assay. $1,25(\mathrm{OH})_{2} \mathrm{D}_{3}$ binding to cytosol receptor was performed by the method of Costa et al. (11) with minor revisions. $\left[{ }^{3} \mathrm{H}\right] 1,25(\mathrm{OH})_{2} \mathrm{D}_{3}$ and in a parallel assay, radioinert $1,25(\mathrm{OH})_{2} \mathrm{D}_{3}$ and 25 -hydroxyvitamin $\mathrm{D}_{3}\left(25 \mathrm{OHD} \mathrm{D}_{3}\right)$ were dissolved in $10 \mu \mathrm{l}$ of $95 \%$ ethanol and added to borosilicate glass tubes. Aliquots of cytosol containing 200-300 $\mu \mathrm{g}$ of protein in $80 \mu \mathrm{l}$ were added to each tube, and the tubes were incubated at $4^{\circ} \mathrm{C}$ for $20 \mathrm{~h}$. Bound and free hormone were separated by the addition of dextran-coated charcoal. The charcoal solution was prepared in borate buffer containing $5 \%$ acid washed Norit A and $0.5 \%$ dextran T-70. $50 \mu \mathrm{l}$ of charcoal was added to $100 \mu \mathrm{l}$ of cytosol and steroid. The samples were vortexed, allowed to stand on ice for $15 \mathrm{~min}$, and centrifuged at $3500 \mathrm{~g}$ for $50 \mathrm{~min}$.
Nonspecific binding was determined in each experiment from the radioactivity that remained in the bound fraction (receptor$1,25(\mathrm{OH})_{2} \mathrm{D}_{3}$ complex) after incubation in the presence of 250 -fold excess of radioinert $1,25(\mathrm{OH})_{2} \mathrm{D}_{3}$ and 100 -fold excess of $25 \mathrm{OHD}_{3}$. Nonspecific binding was determined in each assay and subtracted from total binding to yield specific binding.

Density gradients. Aliquots of cytosol fraction ( $800 \mu \mathrm{g}$ of protein) were incubated with $\left[{ }^{3} \mathrm{H}\right] 1,25(\mathrm{OH})_{2} \mathrm{D}_{3}$ and radioinert $1,25(\mathrm{OH})_{2} \mathrm{D}_{3}$ and $25 \mathrm{OHD}_{3}$ for $20 \mathrm{~h}$ at $4^{\circ} \mathrm{C}$. $\left[{ }^{3} \mathrm{H}\right] 1,25(\mathrm{OH})_{2} \mathrm{D}_{3}$-receptor complex was separated from unbound steroid using charcoal/dextran and centrifugation. The steroid-receptor (bound) fraction was layered onto linear $10-35 \%$ sucrose gradients developed in cellulose nitrate tubes in hypertonic buffer using a gradient mixer (Buchler Instruments, Inc., Ft. Lee, $\mathrm{NJ}$ ). After centrifugation at $4^{\circ} \mathrm{C}$ for $22 \mathrm{~h}$ at $150,000 \mathrm{~g}$ (Beckman Instruments ultracentrifuge, $\mathrm{SW}-50.1$ rotor), $0.15-\mathrm{ml}$ fractions were collected from the bottom of the gradient tubes using a density gradient-fractionater recovery system. Radioactivity in each aliquot was determined by beta liquid scintillation counting.

$V$ itamin $D$ receptor $m R N A$ isolation and quantification. Duodenal mucosa was scraped from underlying muscle layers, rinsed in ice-cold phosphate-buffered saline, flash frozen in liquid nitrogen, and stored at $-70^{\circ} \mathrm{C}$. Total cellular RNA was extracted from frozen tissue by the method of Komm et al. $(27,28)$. Poly $(A)^{+}$RNA was purified by oligo(dT)-cellulose (type 3, Collaborative Research, Inc., Waltham, MA) affinity chromatography (29). Northern hybridization analysis of rat vitamin $D$ receptor $m R N A$ was performed as described previously for the chicken vitamin $D$ receptor (13). Briefly, $10 \mu \mathrm{g}$ of duodenal poly $(\mathrm{A})^{+} \mathrm{RNA}$ was denatured at $55^{\circ} \mathrm{C}$ in $50 \%$ formamide and $6.5 \%$ formaldehyde, electrophoresed in a $1 \%$ agarose-formaldehyde gel, and electrotransferred to a Nytran membrane (Schleicher \& Schuell, Inc., Keene, $\mathrm{NH}$ ) in a morpholino propane sulfonic acid-sodium acetateEDTA buffer (30). After an initial prehybridization of the Nytran membrane, rat receptor mRNA was hybridized with $10^{6} \mathrm{cpm} / \mathrm{ml}$ of a nick-translated fragment of the human vitamin $\mathrm{D}$ receptor cDNA $\left(2 \times 10^{8} \mathrm{dpm} / \mathrm{ug}\right)$. The human vitamin $\mathrm{D}$ receptor cDNA fragment contains the coding region for the entire DNA-binding domain of the receptor that is homologous to the chicken vitamin $D$ receptor $(13,31)$ and cross-hybridizes at high stringency with vitamin $D$ receptor mRNAs from all avian and mammalian species tested (32). After hybridization, the Nytran filter was washed four times, 5 min each at room temperature with $1 \times$ standard saline citrate (SSC) $(150 \mathrm{mM}$ $\mathrm{NaCl}, 15 \mathrm{mM} \mathrm{Na}_{3}$ citrate, $\mathrm{pH} 7.0$ ), $0.1 \%$ SDS, followed by two highstringency washes for $15 \mathrm{~min}$ each at $55^{\circ} \mathrm{C}$ with $0.1 \times \mathrm{SSC}, 0.1 \%$ SDS. Vitamin $D$ receptor mRNA bands were visualized by autoradiography and quantitated by laser densitometric scanning. As an internal control the same Nytran filter was stripped and rehybridized to a nicktranslated actin cDNA probe. The quantitation of vitamin $D$ receptor mRNA is based on scanning of actin mRNA amounts in each lane.

Serum chemistries. Serum calcium and magnesium were determined by atomic absorption spectrometry, and serum phosphate and creatinine by standard autoanalyzer methodology. Serum $1,25(\mathrm{OH})_{2} \mathrm{D}_{3}$ was measured on $1.0 \mathrm{ml}$ of serum from individual rats by radioreceptor assay as previously described (33). All samples were analyzed in a single assay.

Materials. ${ }^{45} \mathrm{CaCl}_{2}$ and $1,25(\mathrm{OH})_{2}-\left[23,24(\mathrm{n})-\left[{ }^{3} \mathrm{H}\right]\right.$ vitamin $\mathrm{D}_{3}(110$ $\mathrm{Ci} / \mathrm{mmol}$ ) were obtained from Amersham Searle Co. (Arlington Heights, IL). $\left[\gamma^{32} \mathrm{P}\right] \mathrm{dCTP}(3,000 \mathrm{Ci} / \mathrm{mmol})$ used for nick translation was purchased from New England Nuclear (Boston, MA). Crystalline $1,25(\mathrm{OH})_{2} \mathrm{D}_{3}$ was a gift from Dr. M. Uskokovic, Hoffmann-LaRoche Co. (Nutley, $\mathrm{NJ}$ ); crystalline 25 -hydroxyvitamin $\mathrm{D}_{3}$ was a gift from The Upjohn Co. (Kalamazoo, MI). Other chemicals were obtained from Sigma Chemical Co. (St. Louis, MO).

Statistical analyses. Significance of differences between two group means was estimated by Student's $t$ test. Variances within groups were not assumed to be equal. All calculations were performed using conventional computer techniques (BMDP, University of California, Los Angeles). Values are expressed as mean \pm SE. $P$ values $<0.05$ are considered significant. 


\section{Results}

Calcium active transport. Rats fed NCD actively absorbed calcium across duodenum, as calcium $J_{\mathrm{ms}}$ exceeded $J_{\mathrm{sm}}$ (Table I). 3 wk of LCD increased duodenal net calcium absorption from $39 \pm 20$ to $187 \pm 46 \mathrm{nmol} / \mathrm{cm}^{2} \cdot \mathrm{h}$ (Table I). The increase in $J_{\text {net }}$ was due to an increase in $J_{\mathrm{ms}}$ without a change in $J_{\mathrm{sm}}$, a predictable response by duodenum to LCD (3).

In contrast to duodenum, there was net calcium secretion across jejunum from rats fed NCD, as calcium $J_{\text {sm }}$ exceeded calcium $J_{\mathrm{ms}}$ (Table I). LCD increased calcium $J_{\mathrm{ms}}$, and converted jejunum from net calcium secretion to net absorption. LCD increased $J_{\mathrm{ms}}$ greater in duodenum than jejunum, by an average of 139 vs. $23 \mathrm{nmol} / \mathrm{cm}^{2} \cdot \mathrm{h}$, so calcium $J_{\text {net }}$ during LCD was greater in duodenum than jejunum. As anticipated, shortcircuit current $\left(I_{\mathrm{sc}}\right)$ was greater in jejunum than duodenum (Table I). $G_{t}$ was comparable in duodenum and jejunum, and both $G_{\mathrm{t}}$ and $I_{\mathrm{sc}}$ were unaffected by diet.

Serum chemistries. 3 wk of a dietary calcium restriction increased circulating $1,25(\mathrm{OH})_{2} \mathrm{D}_{3}$ levels sixfold from $27 \pm 3$ to $181 \pm 17 \mathrm{pg} / \mathrm{ml}$ (Table II). Serum calcium, magnesium, phosphorus, and creatinine levels during NCD were not changed by LCD.

Sucrose density analysis. Sucrose density gradients were used to characterize the binding of $\left[{ }^{3} \mathrm{H}\right] 1,25(\mathrm{OH})_{2} \mathrm{D}_{3}$ to macromolecules in the cytosol fraction of intestinal homogenates. As shown in Fig. $1,\left[{ }^{3} \mathrm{H}\right] 1,25(\mathrm{OH})_{2} \mathrm{D}_{3}(1.2 \mathrm{nM})$ appeared as a single peak that sedimented at about $3.5 \mathrm{~S}$, characteristic of the vitamin $\mathrm{D}$ receptor $(17,18)$. 250 -fold excess of $1,25(\mathrm{OH})_{2} \mathrm{D}_{3}$ virtually abolished binding of $\left[{ }^{3} \mathrm{H}\right] 1,25(\mathrm{OH})_{2} \mathrm{D}_{3} \cdot\left[{ }^{3} \mathrm{H}\right] 25 \mathrm{OHD}$ $(0.7 \mathrm{nM})$ appeared primarily in one peak that sedimented at about $6 S$ with minimal binding in the $3.5 S$ region. The $6 S$ peak is thought to represent binding to the plasma vitamin D-binding protein, which has higher affinity for $25 \mathrm{OHD}_{3}$ than $1,25(\mathrm{OH})_{2} \mathrm{D}_{3}(34)$. On the basis of these studies, subsequent experiments were performed in the presence of excess $25 \mathrm{OHD}_{3}$ as well as $1,25(\mathrm{OH})_{2} \mathrm{D}_{3}$ to eliminate binding of $1,25(\mathrm{OH})_{2} \mathrm{D}_{3}$ to any vitamin $\mathrm{D}$-binding protein that may have contaminated the cytosol preparation. Sucrose density gradient analyses of intestinal cytosol preparations from rats either fed NCD or LCD revealed comparable patterns of $\left[{ }^{3} \mathrm{H}\right]-$ $1,25(\mathrm{OH})_{2} \mathrm{D}_{3}$ binding (data not shown).

In vitro $1,25(\mathrm{OH})_{2} \mathrm{D}_{3}$ binding to cytosol fraction. Duodenal

Table I. Effects of LCD on Duodenal and Jejunal Calcium Active Transport

\begin{tabular}{lcccccc}
\hline Group & $n$ & $J_{\mathrm{ms}}$ & $J_{\mathrm{mm}}$ & $J_{\text {net }}$ & $I_{\mathrm{sc}}$ & $G_{\mathrm{t}}$ \\
\hline \multicolumn{7}{c}{$\mathrm{nmol} / \mathrm{cm}^{2} \cdot h$} \\
Duodenum \\
$\quad$ NCD & 8 & $65 \pm 21$ & $26 \pm 6$ & $39 \pm 20$ & $75 \pm 10$ & $16 \pm 1$ \\
LCD & 6 & $204 \pm 47^{*}$ & $17 \pm 3$ & $187 \pm 46^{\ddagger}$ & $97 \pm 9$ & $15 \pm 1$ \\
Jejunum & & & & & & \\
$\quad$ NCD & 8 & $23 \pm 3$ & $28 \pm 4$ & $-5 \pm 3$ & $117 \pm 20$ & $12 \pm 1$ \\
LCD & 9 & $46 \pm 4^{\S}$ & $25 \pm 3$ & $21 \pm 5^{\S}$ & $147 \pm 10$ & $11 \pm 1$ \\
& & & & & &
\end{tabular}

Values are mean \pm SEM for $n$ rats per group. $J_{\text {net }}$, net flux $=J_{\mathrm{ms}}-J_{\mathrm{sm}}$.

* Greater than NCD, $P<0.01$.

* Greater than NCD, $P<0.006$.

${ }^{8}$ Greater than NCD, $P<0.007$.
Table II. Effects of Dietary Calcium Restriction on Serum $1,25(\mathrm{OH})_{2} \mathrm{D}$ and Other Chemistries

\begin{tabular}{ccccccc}
\hline Diet & $n$ & $\mathrm{Ca}$ & $\mathrm{Mg}$ & $\mathrm{P}$ & Creatinine & $1,25(\mathrm{OH})_{2} \mathrm{D}$ \\
\hline \multicolumn{5}{c}{$m g / d l$} \\
$\mathrm{NCD}$ & 7 & $10.5 \pm 0.5$ & $2.2 \pm 0.1$ & $7.6 \pm 0.3$ & $0.4 \pm 0.02$ & $27 \pm 3$ \\
LCD & 8 & $10.4 \pm 0.3$ & $2.2 \pm 0.1$ & $7.7 \pm 0.8$ & $0.4 \pm 0.01$ & $181 \pm 17^{*}$
\end{tabular}

Values are mean \pm SEM for $n$ rats per group.

$* P<0.001$

cytosolic fraction pooled from two rats fed LCD bound progressively greater amounts of $\left[{ }^{3} \mathrm{H}\right] 1,25(\mathrm{OH})_{2} \mathrm{D}_{3}$ as higher concentrations of the tritium-labeled steroid were added (Fig. 2). Nonspecific binding was $<5 \%$ of total binding at all concentrations of $1,25(\mathrm{OH})_{2} \mathrm{D}_{3}$. Duodenal cytosol fractions prepared from rats fed $L C D$ bound more $\left[{ }^{3} \mathrm{H}\right] 1,25(\mathrm{OH})_{2} \mathrm{D}_{3}$ than cytosolic fractions from rats fed NCD (Fig. 3). In rats fed NCD, cytosol binding from duodenum (Fig. 3) and jejunum (Fig. 4) were comparable, and LCD increased specific $\left[{ }^{3} \mathrm{H}\right]-$ $1,25(\mathrm{OH})_{2} \mathrm{D}_{3}$ binding in jejunum and duodenum to the same extent (compare Figs. 3 and 4).

To determine whether the increase in $\left[{ }^{3} \mathrm{H}\right] 1,25(\mathrm{OH})_{2} \mathrm{D}_{3}$ specific binding was due to an increase in the number of binding sites or to a change in the affinity of the receptor for the steroid, the binding data was subjected to Scatchard analysis. For duodenum from rats fed NCD (Fig. 5), Scatchard plots revealed a single class of binding sites with a $K_{d}$ of $0.17 \pm 0.06$ $\mathrm{nM}$ (mean $\pm \mathrm{SE}$ of four experiments). Cytosol fractions from duodenum of rats fed LCD also contained a single class of

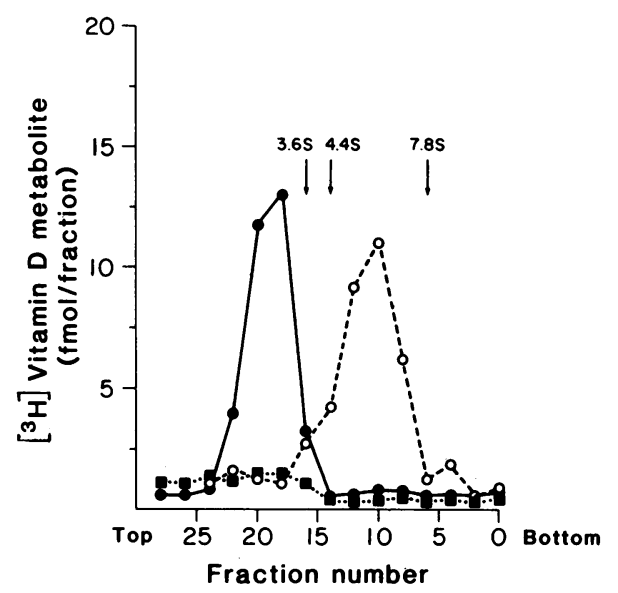

Figure 1. Analysis of $\left[{ }^{3} \mathrm{H}\right] 1,25(\mathrm{OH})_{2} \mathrm{D}_{3}$ and $\left[{ }^{3} \mathrm{H}\right] 25 \mathrm{OHD}$ binding to intestinal cytosol receptor by sucrose density gradient analysis. Cytosol fraction (see Methods) prepared from homogenates of duodenal epithelial cells was incubated in the presence of $\left[{ }^{3} \mathrm{H}\right] 1,25(\mathrm{OH})_{2} \mathrm{D}_{3}$ $(1.2 \mathrm{nM})$ for $20 \mathrm{~h}$ at $4^{\circ} \mathrm{C}$. Bound and free $\left[{ }^{3} \mathrm{H}\right] 1,25(\mathrm{OH})_{2} \mathrm{D}_{3}$ was separated by dextran-coated charcoal. The bound fraction $(800 \mu \mathrm{g}$ of protein) was layered on a linear $10-35 \%$ sucrose gradient and centrifuged at $150,000 \mathrm{~g}$ for $22 \mathrm{~h}$. (๑) $\left[{ }^{3} \mathrm{H}\right] 1,25(\mathrm{OH})_{2} \mathrm{D}_{3}(1.2 \mathrm{nM}) ;(\mathrm{O}--\mathrm{O})$ $\left[{ }^{3} \mathrm{H}\right] 25 \mathrm{OHD}_{3}(0.7 \mathrm{nM})$; and $(\bullet \cdots)\left[{ }^{3} \mathrm{H}\right] 1,25(\mathrm{OH})_{2} \mathrm{D}_{3}$ with $1,25(\mathrm{OH})_{2} \mathrm{D}_{3}(300 \mathrm{nM})$. Internal standards include: aldolase, 7.8S; bovine serum albumin, $4.4 S$; and ovalbumin, 3.6S. Duodenal cytosol from rats fed NCD was used in this study. Comparable results were obtained with duodenal cytosol from rats fed LCD and with jejunal cytosol from rats fed NCD or LCD. 


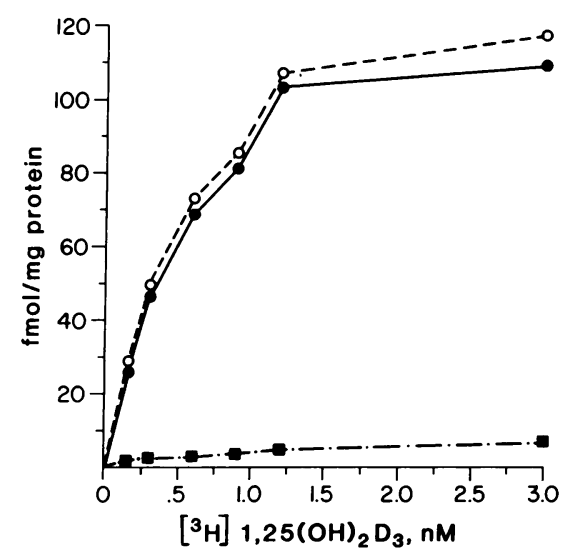

Figure 2. Binding of $\left[{ }^{3} \mathrm{H}\right] 1,25(\mathrm{OH})_{2} \mathrm{D}_{3}$ to duodenal cytosol fraction prepared from rats fed LCD (see Methods). $\left[{ }^{3} \mathrm{H}\right] 1,25(\mathrm{OH})_{2} \mathrm{D}_{3}$ was incubated with cytosol fraction for $22 \mathrm{~h}$ at $4^{\circ} \mathrm{C}$. Bound and free hormone were separated by dextran-coated charcoal. Specific hormone binding (๑) was calculated as the difference between total binding ( 0 ) and nonspecific binding $(\square)$. The latter was the amount of bound $\left[{ }^{3} \mathrm{H}\right]-$ $1,25(\mathrm{OH})_{2} \mathrm{D}_{3}$ after incubation in the presence of 250 -fold excess $1,25(\mathrm{OH})_{2} \mathrm{D}_{3}$ and 100 -fold excess $25 \mathrm{OHD}_{3}$. Comparable binding curves were obtained from duodenal cytosol from rats fed NCD and jejunal cytosol from rats fed NCD or LCD.

binding sites; however, the number of specific binding sites was increased threefold compared with NCD (32.9 \pm 6.7 vs. $98.7 \pm 13.7 \mathrm{fmol} 1,25(\mathrm{OH})_{2} \mathrm{D}_{3} / \mathrm{mg}$ protein). The affinity of $1,25(\mathrm{OH})_{2} \mathrm{D}_{3}$ for the duodenal receptor was not altered by LCD $\left(K_{d} 0.21 \pm 0.02 \mathrm{nM}\right)$. Receptor number in jejunum was increased 2.5 -fold by $L C D$ (NCD vs. LCD, $34.1 \pm 9.5$ vs. $84.9 \pm 7.7 \mathrm{fmol} / \mathrm{mg}$ protein). As in duodenum, LCD did not alter the affinity of the receptor for $1,25(\mathrm{OH})_{2} \mathrm{D}_{3}$ in jejunum $(0.18 \pm 0.04$ vs. $0.14 \pm 0.02 \mathrm{nM}, \mathrm{NCD}$ vs. $\mathrm{LCD})$, and receptor affinity in duodenum and jejunum were not different.

$1,25(\mathrm{OH})_{2} \mathrm{D}_{3}$ receptor $m \mathrm{RNA}$ content of duodenal epithelium. Northern blot hybridization analysis with polyadenylated RNA extracted from duodenal mucosa revealed one

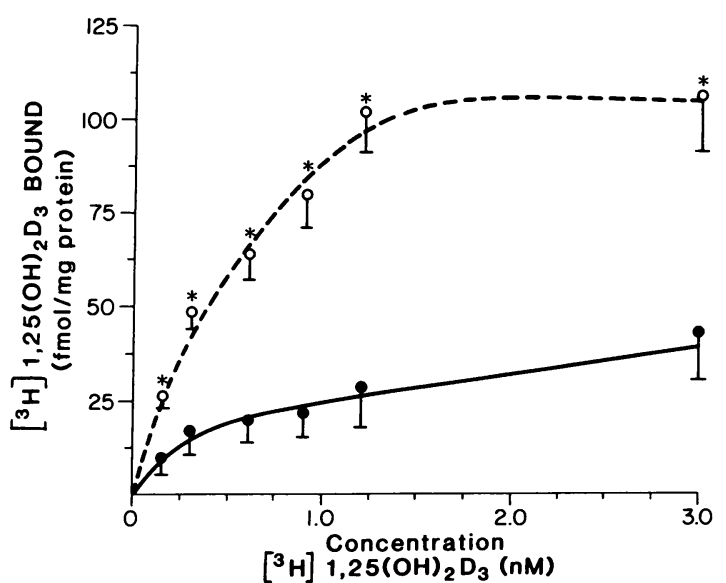

Figure 3. Specific binding of $\left[{ }^{3} \mathrm{H}\right] 1,25(\mathrm{OH})_{2} \mathrm{D}_{3}$ to duodenal cytosol fraction (see Methods) prepared from rats fed NCD (๑) or LCD (0). Values are mean $\pm \mathrm{SE}$ for four observations per group. ${ }^{*} P<0.01$, LCD vs. NCD.

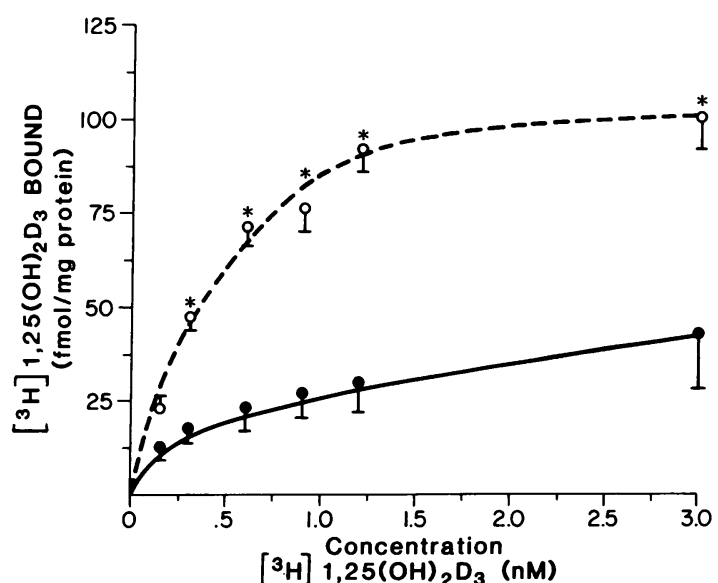

Figure 4. Specific binding of $\left[{ }^{3} \mathrm{H}\right] 1,25(\mathrm{OH})_{2} \mathrm{D}_{3}$ to jejunal cytosol fraction (see Methods) prepared from rats fed NCD (•) or LCD (0). Values are mean $\pm \mathrm{SE}$ for four observations per group. ${ }^{*} P<0.01$, LCD vs. NCD.

mRNA species of $4.5 \mathrm{~kb}$ (Fig. 6). The size of the rat vitamin D receptor mRNA is equivalent to the human receptor and larger than the 2.6-kb mRNA for avian vitamin D receptor (32). 3 wk of LCD did not dramatically increase mucosal vitamin D receptor mRNA content compared to tissue extracts from rats fed NCD. There was an apparent slight enhancement by LCD of the 4.5-kb vitamin D receptor transcript (compare lanes 1 and 2 of Fig. 6), but when the actin mRNA in both lanes was scanned with laser densitometry, this difference was minimized to a value of $<30 \%$ after normalization against the actin mRNA concentration.

\section{Discussion}

In this study the modulating activity of $1,25(\mathrm{OH})_{2} \mathrm{D}_{3}$ on intestinal vitamin $\mathrm{D}$ receptor content was examined at both the cellular and molecular level. Cultured pig kidney cell line LLC-PK 1 (11, 20), human skin fibroblasts $(11,15)$, and mouse 3 T6 fibroblasts $(13,14)$ contain the vitamin D receptor, and

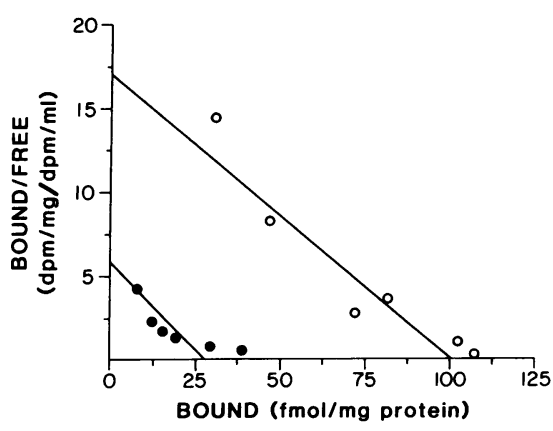

Figure 5. Scatchard plot of specific binding derived from saturation assay of the $1,25(\mathrm{OH})_{2} \mathrm{D}_{3}$ receptor in duodenal cytosol fraction from rats fed NCD (๑) or LCD (0). The maximum number of binding sites (Vmax) of four experiments was $32.9 \pm 6.7$ and $98.7 \pm 13.7 \mathrm{fmol} /$ $\mathrm{mg}$ (mean $\pm \mathrm{SE}$ ) for NCD and LCD rats, respectively. $K_{\mathrm{d}}$ values were $0.17 \pm 0.06$ and $0.21 \pm 0.02 \mathrm{nM}$ for NCD and LCD, respectively. 


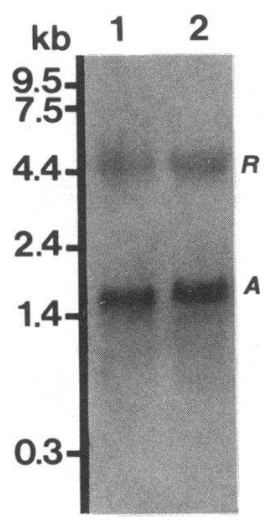

Figure 6. Northern blot analysis of polyadenylated mRNA isolated from rat intestine. Duodenal polyadenylated RNA (10 $\mu \mathrm{g}$ each) from rats fed NCD (lane 1 ) and LCD (lane 2) were isolated (see Methods), subjected to electrophoresis on a $1 \%$ agarose-formaldehyde gel, and electrotransferred to a nylon membrane. After an initial prehybridization of the nylon filter for $2 \mathrm{~h}$, the filter was probed with a human vitamin $\mathrm{D}$ cDNA nick-translated fragment $\left(10^{6} \mathrm{cpm} / \mathrm{ml}\right)$ in new hybridization buffer. Autoradiography was performed for $72 \mathrm{~h}$. After stripping and rehybridizing the same filter with an actin cDNA probe, the resulting actin Northern blot film was superimposed upon a photograph of the vitamin D receptor blot to create a composite illustration. The film overlay does not place the actin at the exact size for this transcript $(1.8 \mathrm{~kb})$ and also accounts for the higher general background. $R$, vitamin D receptor mRNA; $A$, actin mRNA.

addition of $1,25(\mathrm{OH})_{2} \mathrm{D}_{3}$ or $24,25-(\mathrm{OH})_{2} \mathrm{D}_{3}$ increases the vitamin D receptor content two- to four-fold with no change in affinity for $1,25(\mathrm{OH})_{2} \mathrm{D}_{3}$. Although the studies in vitro clearly demonstrate homologous upregulation of the vitamin $\mathrm{D}$ receptor by $1,25(\mathrm{OH})_{2} \mathrm{D}_{3}$ and active metabolites, studies in vivo suggested $1,25(\mathrm{OH})_{2} \mathrm{D}_{3}$ may either cause no change in receptor content (16) or the increase may be organ-specific (19). Hunziker et al. (16) found no increase in the intestinal receptor after acute $1,25(\mathrm{OH})_{2} \mathrm{D}_{3}$ repletion of vitamin $\mathrm{D}$-deficient chicks. Costa and Feldman (19) found a threefold increase in vitamin D receptor content in kidney from vitamin D-deficient rats after $5 \mathrm{~d}$ of repletion with $1,25(\mathrm{OH})_{2} \mathrm{D}_{3}$. However, intestinal vitamin D receptor was increased by only $30 \%$ in these same animals. The threefold increase in intestinal vitamin D receptor content during LCD in the present study clearly shows that intestinal vitamin $\mathrm{D}$ receptor upregulation can occur in vivo. The difference between the results of the present study and the lack of a substantial increase in receptor in acutely repleted vitamin D-deficient animals suggest that 5 d or fewer of $1,25(\mathrm{OH})_{2} \mathrm{D}_{3}$ administration to vitamin D-deficient animals may be insufficient.

Accumulation of the vitamin D receptor observed in the present study may be the result of increased rate of receptor synthesis, decreased rate of receptor degradation, or a combination of both processes. The increase in intestinal vitamin $D$ receptor by $L C D$ appears not to be due to an increase in new receptor synthesis, since the mRNA that specifically encodes for the receptor protein increased only very slightly $(<30 \%)$, whereas intestinal receptor content increased threefold. Thus, the present study suggests that regulation may be controlled at several levels, including an extremely minor transcriptional component and a major effect on posttranslational events to depress the rate of receptor degradation. The observations in the present study are partially consistent with measurements in vitro of receptor protein and its mRNA in 3T6 mouse fibroblast cells $(13,14)$. Recently, Mangelsdorf et al. (14) have employed in vitro translation and immunoprecipitation techniques to examine $1,25(\mathrm{OH})_{2} \mathrm{D}_{3}$ regulation of its receptor in 3 T6 cells. These studies revealed a complex system that involves both transcriptional and posttranslational components.
It is known that one of these posttranslational events is due to receptor phosphorylation (35). Although the consequence of receptor phosphorylation has not yet been defined, it is likely to involve receptor regulation (36) and may function to stabilize the hormone-bound form of the vitamin D receptor, thereby increasing the net concentration of active receptor in the cell. The suggestion that $1,25(\mathrm{OH})_{2} \mathrm{D}_{3}$ can decrease the degradation rate of the vitamin $\mathrm{D}$ receptor is further supported by receptor turnover studies in LLC-PK 1 cells (20). Using the dense amino acid shift technique to study the turnover of vitamin $\mathrm{D}$ receptors before and after receptor upregulation by $24,25(\mathrm{OH})_{2} \mathrm{D}_{3}$, Costa and Feldman (20) found upregulated cells synthesized receptor at a slightly increased rate $(4.9 \pm 0.5$ $\mathrm{fmol} / \mathrm{mg}$ protein per hour vs. $3.4 \pm 0.4$ for controls), whereas the receptor half-life was doubled from $4.3 \pm 0.4$ to $8.9 \pm 1.0 \mathrm{~h}$. The degradation rate of the receptor under basal conditions was $0.16 / \mathrm{h}$ and $0.07 / \mathrm{h}$ during upregulation. Although LCD may have increased receptor synthesis with minimal increase in mRNA through an increase in protein copy rate, studies specifically designed to address the effect of $1,25(\mathrm{OH})_{2} \mathrm{D}_{3}$ on message copy rate and receptor stability will be required to address these issues.

It is known that receptor occupancy reduces the rate of degradation of the vitamin $D$ receptor $(17,18)$, and whereas a portion of the increased receptor content observed in the present study could be receptor stabilization from increased ligand binding, several lines of evidence from in vitro studies argue against this interpretation, including the following: the persistence of increased receptor at least $4 \mathrm{~h}$ after removal of the steroid from the cells (11); skin fibroblasts from patients with vitamin D resistant rickets, which contain a mutant vitamin $D$ receptor and do not upregulate the receptor, bind $1,25(\mathrm{OH})_{2} \mathrm{D}_{3}$ but do not bind to DNA (11); the relatively long period of time required for steroid to induce maximal receptor binding $(11,13,20)$; and the marked inhibition of receptor upregulation after $24 \mathrm{~h}$ of exposure to actinomycin D (11).

The weight of evidence supports a critical role of the vitamin $D$ receptor in mediating the biological responses to $1,25(\mathrm{OH})_{2} \mathrm{D}_{3}$ in the intestine. Endogenous occupancy of intestinal receptors is $10-25 \%$ in vitamin $D$ replete rats, and $1,25(\mathrm{OH})_{2} \mathrm{D}_{3}$ administration increases occupancy to $25-60 \%$ (19). Thus, $1,25(\mathrm{OH})_{2} \mathrm{D}_{3}$ could increase its biologic actions on target tissues by increasing the occupancy of existing receptors. However, without concomitant measurements of biologic responses to $1,25(\mathrm{OH})_{2} \mathrm{D}_{3}$, the physiologic significance of the changes in occupancy are difficult to interpret. The present study suggests that $1,25(\mathrm{OH})_{2} \mathrm{D}_{3}$ may increase its biologic actions on target cells through increased intracellular receptor number. The threefold increase in duodenal receptor number during LCD was accompanied by a threefold increase in duodenal calcium $J_{\mathrm{ms}}$, the $1,25(\mathrm{OH})_{2} \mathrm{D}_{3}$-responsive component of the calcium active transport process (3). Thus, the upregulation of receptor was accompanied by a qualitatively similar increase in a major action of $1,25(\mathrm{OH})_{2} \mathrm{D}_{3}$, increased calcium absorption. Studies in vitro also show a correlation between upregulation of the receptor and expression of a biologic response to $1,25(\mathrm{OH})_{2} \mathrm{D}_{3}$ and metabolites $(11,12,15,20)$. The sixfold increase in serum $1,25(\mathrm{OH})_{2} \mathrm{D}_{3}$ during $\mathrm{LCD}$, is due largely to increased synthesis by renal proximal tubules (21, 33). That the sixfold increase in circulating levels enhanced intestinal receptor number by threefold suggests that the rela- 
tionship between serum $1,25(\mathrm{OH})_{2} \mathrm{D}_{3}$ and intestinal receptor binding is complex and will require detailed studies of in vivo binding kinetics between blood $1,25(\mathrm{OH})_{2} \mathrm{D}_{3}$ and intracellular vitamin $\mathrm{D}$ receptor to clarify the interactions.

Duodenum and jejunum differ in calcium transport kinetics, with a higher secretory flux $\left(J_{\mathrm{sm}}\right)$ in jejunum and a greater response to endogenous and exogenous $1,25(\mathrm{OH})_{2} \mathrm{D}_{3}$ in duodenum (3). In the present study receptor content in duodenum and jejunum from rats fed NCD or LCD were equivalent, whereas Feldman et al. (18) found a progressive decline in receptor content from duodenum to ileum in vitamin D-deficient rats. Although regional receptor concentration differences between the present study and that of Feldman may be due to the vitamin $\mathrm{D}$ status of the animals, diminished calcium transport response by jejunum to $1,25(\mathrm{OH})_{2} \mathrm{D}_{3}$ cannot be due to a difference in vitamin $D$ receptor-binding sites, since basal receptor content in duodenum and jejunum were equivalent, and LCD caused a comparable increase in receptor number in both regions. It is also unlikely that greater cellularity of duodenum accounts for differences in receptor content and higher calcium transport rates, since cecum is devoid of villi and has higher calcium transport rates than duodenum, and cellular phosphate transport is greatest in jejunum $(3,37)$, which is also less cellular than duodenum. The apparent discrepancy between segmental calcium transport and receptor number do not negate the important role of receptor binding in reaching steady-state calcium transport rates. Rather, the cellular response to $1,25(\mathrm{OH})_{2} \mathrm{D}_{3}$ appears to be modified by events subsequent to the synthesis of the vitamin $\mathrm{D}$ receptor.

\section{Acknowledgments}

The authors thank Melissa Tanklefsky and Karen Ambrosic for their technical assistance and Kathy Cobb for her assistance in preparation of the manuscript.

This research was supported by grants DK-33949, DK-36802, DK-33351, and AR-15781 from the National Institutes of Health.

\section{References}

1. Walling, M. W., and S. S. Rothman. 1969. Phosphate-independent, carrier-mediated active transport of calcium by rat intestine. Am. J. Physiol. 217:1133-1148.

2. Favus, M. J., M. W. Walling, and D. V. Kimberg. 1973. Effects of 1,25-dihydroxycholecalciferol on intestinal calcium transport in cortisone-treated rats. J. Clin. Invest. 52:1680-1685.

3. Favus, M. J. 1985. Factors that influence absorption and secretion of calcium in the small intestine and colon. Am. J. Physiol. 248:G147-G157.

4. Haussler, M. R., and A. W. Norman. 1969. Chromosomal receptor for a vitamin D metabolite. Proc. Natl. Acad. Sci. USA. 62:155-162.

5. Brumbaugh, P. F., and M. R. Haussler. 1975. Specific binding of 1,25-dihydroxycholecalciferol to nuclear components of chick intestine. J. Biol. Chem. 250:1588-1594.

6. Brumbaugh, P. F., M. R. Hughes, and M. R. Haussler. 1975. Cytoplasmic and nuclear binding components for 1,25-dihydroxyvitamin $\mathrm{D}_{3}$ in chick parathyroid glands. Proc. Natl. Acad. Sci. USA. 72:4871-4875.

7. Haussler, M. R., S. C. Manolagos, and L. J. Deftos. 1980. Evidence for a 1,25-dihydroxyvitamin $\mathrm{D}_{3}$ receptor-like macromolecule in rat pituitary. J. Biol. Chem. 255:5007-5010.

8. Pike, J. W., and M. R. Haussler. 1979. Purification of chicken intestinal receptor for 1,25-dihydroxyvitamin D. Proc. Natl. Acad. Sci. USA. 76:5485-5489.

9. Pike, J. W. 1982. Interaction between 1,25-dihydroxyvitamin $D_{3}$ receptors and intestinal nuclei. J. Biol. Chem. 257:6766-6775.

10. Haussler, M. R. 1986. Vitamin D receptors: nature and function. Annu. Rev. Nutr. 6:527-562.

11. Costa, E. M., M. A. Hirst, and D. Feldman. 1985. Regulation of 1,25-dihydroxyvitamin $D_{3}$ receptors by vitamin $D$ analogs in cultured mammalian cells. Endocrinology. 117:2203-2210.

12. Chen, T. L., P. V. Hauschka, S. Cabrales, and D. Feldman. 1986. The effects of 1,25-dihydroxyvitamin $D_{3}$ and dexamethasone on rat osteoblast-like primary cell cultures: receptor occupancy and functional expression patterns for three different bioresponses. Endocrinology. 118:250-259.

13. McDonnell, D. P., D. J. Mangelsdorf, J. W. Pike, M. R. Haussler, and B. W. O'Malley. 1987. Molecular cloning of complementary DNA encoding the avian receptor for vitamin D. Science (Wash. DC). 235:1214-1217.

14. Mangelsdorf, D. J., J. W. Pike, and M. R. Haussler. 1987. Avian and mammalian receptors for 1,25-dihydroxyvitamin $D_{3}$ : in vitro translation to characterize size and hormone-dependent regulation. Proc. Natl. Acad. Sci. USA. 84:354-358.

15. Feldman, D., T. Chen, C. Cone, M. Hirst, S. Shani, A. Benderli, and Z. Hochberg. 1982. Vitamin D resistant rickets with alopecia: cultured skin fibroblasts exhibit defective cytoplasmic receptors and unresponsiveness to $1,25(\mathrm{OH})_{2} \mathrm{D}_{3}$. J. Clin. Endocrinol. Metab. 55:1020-1026.

16. Hunziker, W., M. R. Walters, and A. W. Norman. 1980. 1,25dihydroxyvitamin $D_{3}$ receptors: differential quantitation of endogenously occupied and unoccupied sites. J. Biol. Chem. 255:9534-9537.

17. Kream, B. E., S. Yamada, H. K. Schnoes, and H. F. DeLuca. 1977. Specific cytosol-binding protein for 1,25-dihydroxyvitamin $D_{3}$ in rat intestine. J. Biol. Chem. 252:4501-4505.

18. Feldman, D., T. A. McCain, M. A. Hirst, T. L. Chen, and K. W. Colston. 1979. Characterization of a cytoplasmic receptor-like binder for 1,25-dihydroxycholecalciferol in rat intestinal mucosa. J. Biol. Chem. 254:10378-10384.

19. Costa, E. M., and D. Feldman. 1986. Homologous up-regulation of the $1,25(\mathrm{OH})_{2}$ vitamin $\mathrm{D}_{3}$ receptor in rats. Biochem. Biophys. Res. Commun. 137:742-747.

20. Costa, E. M., and D. Feldman. 1987. Measurement of 1,25-dihydroxyvitamin $D_{3}$ receptor turnover by dense amino acid labeling: changes during receptor up-regulation by vitamin D metabolites. Endocrinology. 120:1173-1178.

21. Langman, C. B., M. J. Favus, D. A. Bushinsky, and F. L. Coe. 1985. Effects of dietary calcium restriction on 1,25-dihydroxyvitamin $\mathrm{D}_{3}$ net synthesis by rat proximal tubules. J. Lab. Clin. Med. 106:286292.

22. Favus, M. J., F. L. Coe, S. C. Kathpalia, A. Porat, P. K. Sen, and L. M. Sherwood. 1982. Effects of chlorothiazide on 1,25-dihydroxyvitamin $D_{3}$, parathyroid hormone, and intestinal calcium absorption in the rat. Am. J. Physiol. 242:G575-G581.

23. Walling, M. W., and S. S. Rothman. 1970. Apparent increase in carrier affinity for intestinal calcium transport following dietary calcium restriction. J. Biol. Chem. 245:5007-5011.

24. Favus, M. J., S. C. Kathpalia, F. L. Coe, and A. E. Mond. 1980. Effects of diet calcium and 1,25-dihydroxyvitamin $D_{3}$ on colon calcium active transport. Am. J. Physiol. 238:G75-G78.

25. Schultz, S. G., and R. Zalusky. 1964. Ion transport in isolated rat ileum: Short-circuit current and $\mathrm{Na}$ fluxes. J. Gen. Physiol. 47:567-587.

26. Field, M., D. Fromm, and I. McColl. 1971. Ion transport in rabbit ileal mucosa. I. Na and $\mathrm{Cl}$ fluxes and short-circuit current. Am. J. Physiol. 220:1388-1396.

27. Komm, B. S., and C. R. Lyttle. 1984. Steroidal regulation of rat uterine in vitro mRNA translation products. J. Steroid Biochem. 21:571-577. 
28. Komm, B. S., F. R. Frankel, J. C. Meyers, and C. R. Lyttle. 1987. Estrogen regulation of alphal(I)-procollagen messenger RNA in the rat uterus. Endocrinology. 120:1403-1410.

29. Aviv, H., and P. Leder. 1972. Purification of biologically active globin messenger RNA by chromatography on oligothymidylic acidcellulose. Proc. Natl. Acad. Sci. USA. 69:1408-1412.

30. Maniatis, T., E. Fritsch, and J. Sambrook. 1982. Molecular Cloning: A Laboratory Manual. Cold Spring Harbor Laboratory Press. Cold Spring Harbor, NY. 202 pp.

31. McDonnell, D. P., D. J. Mangelsdorf, A. Baker, J. Shine, M. R. Haussler, J. W. Pike, and B. W. O'Malley. 1987. Structural and functional analysis of cloned vitamin $\mathrm{D}_{3}$ receptors. J. Bone Mineral Res. 2(Suppl. 2):506a. (Abstr.)

32. Mangelsdorf, D. J., D. P. McDonnell, A. Baker, J. Shine, K. Yamaoka, J. W. Pike, B. W. O'Malley, and M. R. Haussler. 1987. Characterization of 1,25-dihydroxyvitamin $D_{3}$ receptor mRNA by Northern analysis with avian and human cDNA. J. Bone Mineral Res. 2(Suppl. 2):201a. (Abstr.)
33. Favus, M. J., and C. B. Langman. 1986. Evidence for calciumdependent control of 1,25-dihydroxyvitamin $D_{3}$ production by rat kidney proximal tubules. J. Biol. Chem. 261:11224-11229.

34. Kream, B. E., H. F. DeLuca, D. M. Moriarity, N. C. Kendrick, and J. G. Ghazarian. 1979. Origin of 25-hydroxyvitamin $D_{3}$ binding protein from tissue cytosol preparations. Arch. Biochem. Biophys. 792:318-323.

35. Pike, J. W., and N. M. Sleator. 1985. Hormone-dependent phosphorylation of the 1,25-dihydroxyvitamin $D_{3}$ receptor in mouse fibroblasts. Biochem. Biophys. Res. Commun. 131:378-385.

36. Haussler, M. R., D. J. Mangelsdorf, C. A. Donaldson, S. L. Marion, N. M. Sleator, and J. W. Pike. 1987. Receptor-mediated action of the vitamin $\mathrm{D}$ hormone. In Gene Regulation by Steroid Hormones III. A. K. Roy and J. H. Clark, editors. Springer-Verlag, New York. 93-110.

37. Walling, M. W. 1977. Intestinal Ca and phosphate transport: differential responses to vitamin $\mathrm{D}_{3}$ metabolites. Am. J. Physiol. 233:E488-E494. 